\title{
Effects of ketoacidosis on rat apolipoprotein A1 gene expression: a link with acidosis but not with ketones
}

\author{
M J Haas ${ }^{1}$, K Pun ${ }^{1}$, D Reinacher ${ }^{1}$, N C W Wong ${ }^{2}$ and \\ A D Mooradian ${ }^{1}$
}

\author{
${ }^{1}$ Division of Endocrinology, Diabetes and Metabolism, Department of Internal Medicine, \\ Saint Louis University Medical School, St Louis, Missouri 63104, USA \\ ${ }^{2}$ Endocrine Research Group, Department of Medicine and Medical Biochemistry, University of Calgary, \\ Calgary, Alberta Canada T2N 4N1 \\ (Requests for offprints should be addressed to A D Mooradian, Division of Endocrinology, \\ Saint Louis University Medical School, 1402 South Grand Blvd, St Louis, Missouri 63104, USA)
}

\begin{abstract}
To determine if ketoacidosis contributes to reduced apolipoprotein A1 (apoA1) expression in insulindeficient diabetic rats, we examined the regulation of apoA1 gene expression in response to changes in ambient $\mathrm{pH}$ or ketone body concentrations. Hepatic apoAI mRNA levels were reduced $42 \%$ in diabetic rats relative to nondiabetic controls (means \pm s.D.; $321.8 \pm 43.7$ vs $438.7 \pm 58.8$ arbitrary units; $P<0 \cdot 03)$. Neither endogenous apoA1 mRNA nor transcriptional activity of the rat apoA1 gene promoter (from -474 to -7 ) were altered by sodium butyrate or isobutyramide $(0.3 \mathrm{mM}$ to $10 \mathrm{mM}$ ) in Hep G2 or Caco-2 cells. Rat hepatic and intestinal apoA1 mRNA levels, and plasma apoA1 concentration, were not altered $24 \mathrm{~h}$ after isobutyramide administration ( $500 \mathrm{mg} / \mathrm{kg}$ by gavage). When the effect of altering ambient $\mathrm{pH}$ within a wide range commonly encountered in vivo was
\end{abstract}

studied, acidosis $(\mathrm{pH}$ 6.7), relative to alkalosis (pH 7.9), decreased apoAI mRNA levels relative to glyceraldehyde-3-phosphate dehydrogenase mRNA by $47 \%$ in Hep G2 cells $(P<0 \cdot 025)$ and by $24 \%$ in Caco-2 cells $(P<0 \cdot 017)$. Acidosis did not alter cytomegalo virus (CMV)- $\beta$-galactosidase activity, or the activity of the simian virus (SV40) early-region promoter, in either cell line transfected with the respective constructs. The lowering of ambient $\mathrm{pH}$ was associated with a graded reduction in apoAI promoter activity. At $\mathrm{pH} 6 \cdot 7$, apoAI promoter activity was reduced by $75 \%$ compared with promoter activity at $\mathrm{pH} 7 \cdot 9$. These observations indicate that acidosis, but not ketosis, contributes to the reduction in apoA 1 expression during diabetic ketoacidosis by down-regulating apoAI promoter activity.

Fournal of Molecular Endocrinology (2000) 25, 129-139

\section{INTRODUCTION}

Apolipoprotein A1 (apoA1) is the major protein constituent of high density lipoprotein (HDL) (Forte \& McCall 1994, Barter \& Ryek 1996). Epidemiological studies suggest that apoA1 and HDL have cardioprotective properties, presumably because of their roles in reverse cholesterol transport (Miller \& Miller 1975, Franceschini et al. 1991). Reduced plasma HDL due to inhibition of apoA1 synthesis may contribute to the increased incidence of coronary heart disease in diabetes (Solymoss et al. 1995, Despres et al. 1996, Mooradian \& Nowak 1996, Haffner et al. 1998). We recently reported that glucose is a repressor, and insulin an activator of apoA1 transcription, both in vitro and in vivo (Murao et al. 1998). However, ketoacidosis is another metabolic abnormality commonly found in many subjects with uncontrolled type 1 diabetes. Therefore, we postulated that ketoacidosis may have additional effects on apoA1 gene expression that are independent of changes in plasma glucose and insulin levels. Since ketone bodies (Ortiz-Caro et al. 1986, Lazar 1990, deFazio et al. 1992, Zitnik et al. 1995), as well as acidosis (Yamaji et al. 1994, Cassuto et al. 1997), independently modulate the expression of several genes, we evaluated the relative roles of each of these parameters in regulating apoA1 gene expression. 


\section{MATERIALS AND METHODS}

\section{Animals}

Male Fischer 344 rats weighing between $200-300 \mathrm{~g}$ were purchased from Harlan Laboratories, Indianapolis, IN, USA. The rats were rendered diabetic with a single intraperitoneal injection of $45 \mathrm{mg} / \mathrm{kg}$ streptozotocin (Upjohn Co., Kalamazoo, MI, USA), given as a $1 \cdot 3 \%$ solution in citrate buffer $(\mathrm{pH} 4 \cdot 5)$. The rats were killed five days after injection, and the extent of diabetic ketoacidosis was documented by measuring serum glucose concentration using the glucose oxidase method (Beckman glucose analyzer, Beckman Co, Inc., Fullerton, CA, USA), and by measuring serum $\beta$-hydroxybutyrate levels using a commercially available kit (Sigma Chemical Co., St Louis, MO, USA). Another group of ten rats was given $500 \mathrm{mg} / \mathrm{kg}$ isobutyramide by gavage and killed $24 \mathrm{~h}$ later. Isobutyramide, an orally bioavailable butyrate analog, has been shown to stimulate expression of the $\gamma$-globin gene promoter in vivo (Perrine et al. 1994). All rats were killed by exsanguination through the abdominal aorta while under pentobarbital anesthesia $(45 \mathrm{mg} / \mathrm{kg})$. The tissues of interest were excised and snap-frozen in liquid nitrogen for RNA extraction.

\section{Cell culture, transfection, and measurement of reporter gene activity}

Hep G2 human hepatoblastoma cells were grown in Dulbecco's modified Eagle's medium (DMEM) containing $100 \mathrm{mg} / \mathrm{dl}$ glucose, $5 \%$ fetal bovine serum (FBS) and penicillin and streptomycin (100 units $/ \mathrm{ml}$ and $100 \mathrm{~g} / \mathrm{ml}$ respectively). The human intestinal cell line, Caco-2, was maintained in Earl's modified essential medium (EMEM) supplemented with $15 \%$ FBS, non-essential amino acids, $0.11 \mathrm{mg} / \mathrm{ml}$ sodium pyruvate and penicillin and streptomycin. Both cell lines were maintained at $37^{\circ} \mathrm{C}$ in an atmosphere consisting of $5 \% \mathrm{CO}_{2}$ and $95 \%$ air. Cells were transfected with $1 \mu \mathrm{g}$ of the plasmid pA1·474.CAT (Romney et al. 1992) using lipofectamine (Life Technologies, Inc., Gaithersburg, MD, USA). Construction of the pA1·474.CAT plasmid was reported previously (Romney et al. 1992). Briefly, the DNA fragment that spans nucleotides -474 to -7 (relative to the transcriptional start site, +1) of the apoAI gene was synthesized using the polymerase chain reaction (PCR). Two oligonucleotide primers extending from -474 to -438 and from -32 to -7 were added to the PCR reaction using rat genomic DNA as the template. The PCR-amplified product was purified by agarose gel electrophoresis and inserted into the SmaI site of the plasmid pT218R (Pharmacia-Amersham Biotech., Piscataway, NJ, USA) for synthesis of single-stranded DNA and sequence verification. The pA1·474.CAT plasmid was then constructed by inserting the apoAI promoter fragment at the $5^{\prime}$-end of the CAT gene in the vector $\mathrm{pUC}-\mathrm{CAT}$. One gram pCMV.SPORT$\beta$-Gal (Life Technologies, Inc.) was added to all transfections to monitor the efficiency of DNA uptake. After $24 \mathrm{~h}$, the cells were treated with either sodium butyrate or isobutyramide, an analog of butyrate, at various concentrations $(0,0 \cdot 3,1 \cdot 0,3 \cdot 0$, and $10 \mathrm{mM})$. The viability of cells exposed to butyrate and isobutyramide for $24 \mathrm{~h}$ was greater than $90 \%$, as assessed by trypan blue exclusion. To study the effect of acidosis on apoAI gene promoter activity, Hep G2 and Caco-2 cells were exposed to sodium bicarbonate-depleted DMEM supplemented with 5\% FBS, penicillin and streptomycin, and $\quad 50 \mathrm{mM} \quad \mathrm{N}$-2-hydroxyethylpiperazine- $N$-2ethane sulfonic acid (HEPES), adjusted to $\mathrm{pH} 6 \cdot 7$, $7 \cdot 0,7 \cdot 3,7 \cdot 6$, and $7 \cdot 9,24 \mathrm{~h}$ after transfection. After another $24 \mathrm{~h}$, cells were harvested and lyzed by brief sonication (Branson Ultrasonics Corp., Danbury, CT, USA), and cellular debris was removed by centrifugation at $12000 \times \boldsymbol{g}$ for $5 \mathrm{~min}$. To measure $\beta$-galactosidase activity, 10 or $20 \mu \mathrm{l}$ of the supernatant fraction were incubated in $100 \mu$ l of a solution containing $100 \mathrm{mM}$ sodium phosphate $(\mathrm{pH} 7 \cdot 3$ ), $1 \mathrm{mM} \quad \mathrm{MgCl}_{2}, \quad 50 \mathrm{mM}$ 2-mercaptoethanol and $0.67 \mathrm{mg} / \mathrm{ml} \quad O$-nitrophenyl- $\beta$-D-galactopyranoside (Herbomel et al. 1984). When color formation was complete, the reaction was terminated by the addition of $150 \mu \mathrm{l} 1 \mathrm{M}$ sodium carbonate. The reaction was quantified by measuring the absorbance at $420 \mathrm{~nm}$ in a multi-plate reader (SLT Labinstruments, Research Triangle Park, NC, USA). The remaining supernatant fraction was heated at $65{ }^{\circ} \mathrm{C}$ for $7 \mathrm{~min}$ to inactivate endogenous deacetylase activity, and chloramphenicol acetyltransferase (CAT) activity was measured as described previously (Gorman et al. 1982).

\section{Northern blot analysis}

Total RNA was isolated from Hep G2 cells, Caco-2 cells, or rat liver and intestine using a single-step acid guanidinium phenol:chloroform extraction procedure (Chirgwin et al. 1979). Aliquots of total RNA (10-15 $\mu \mathrm{g})$ were separated electrophoretically on a denaturing $1 \%$ agarose gel containing $2 \cdot 2 \mathrm{M}$ formaldehyde (Sambrook et al. 1989). The 18S- and 28S-ribosomal RNA bands were visualized by ethidium bromide staining to ensure equivalent loading of total RNA in each lane. The fractionated RNA was transferred to a nylon membrane 

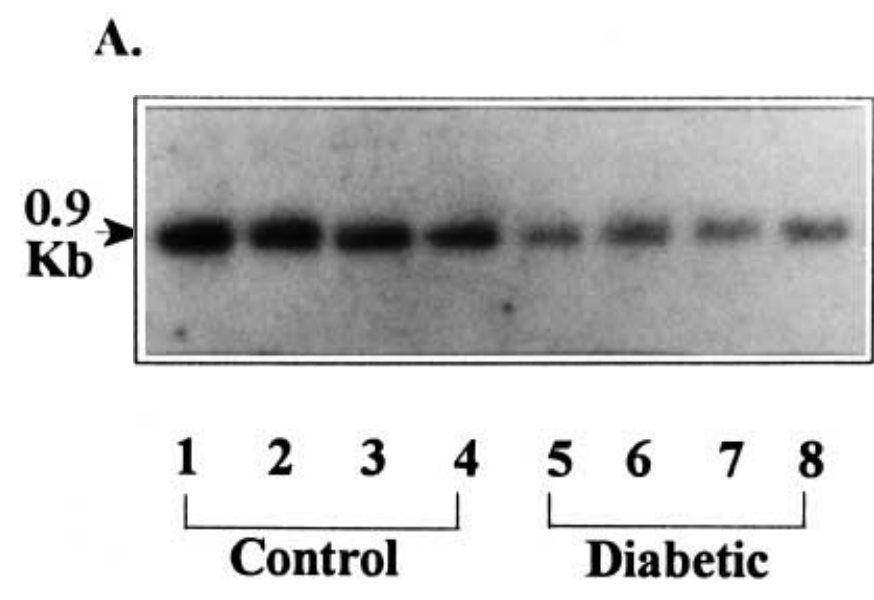

B.

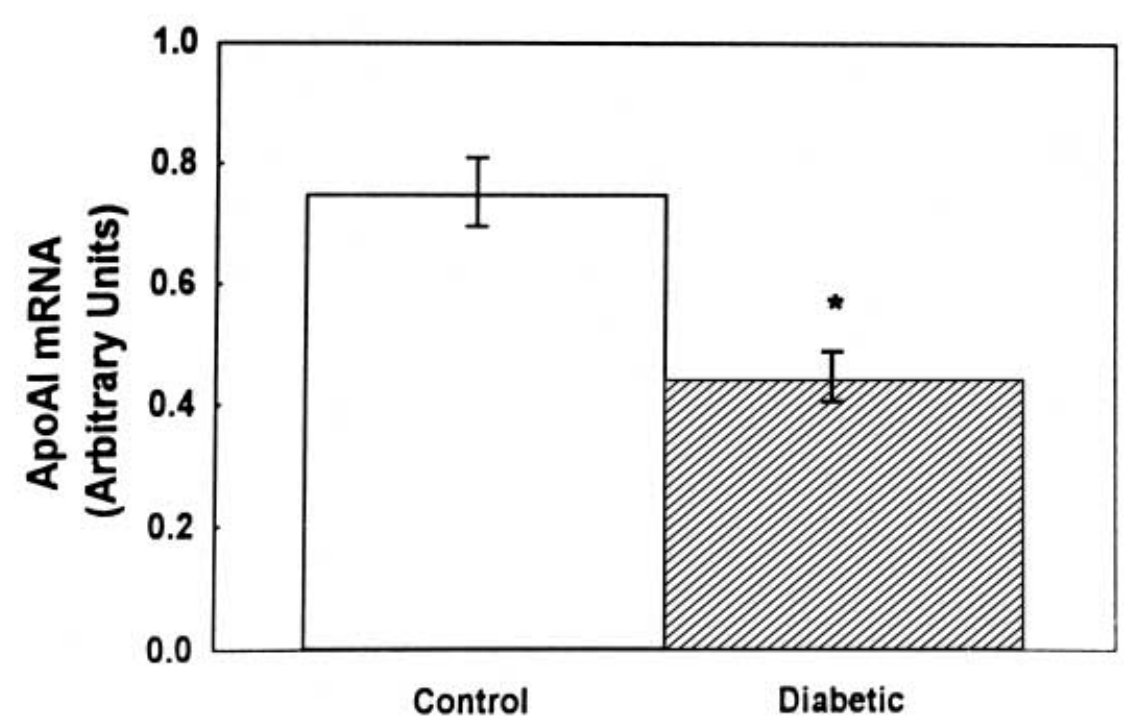

FIGURE 1. Expression of hepatic apoA1 mRNA in euglycemic and streptozotocin-diabetic rats. (A) Northern blot of RNA isolated from the livers of vehicle-injected control rats and rats treated with one dose of streptozotocin five days prior to death. A single $0.9 \mathrm{~kb}$ band of apoAI is observed. (B) The mean ( \pm S.D.) hepatic apoAI mRNA relative to G3 PDH mRNA (in arbitrary units) in diabetic and control rats. $* P<0 \cdot 027$.

(Hybond, Pharmacia-Amersham Biotech.) and probed with a ${ }^{32} \mathrm{P}$-labeled human apoAI cDNA for $2 \mathrm{~h}$ at $65^{\circ} \mathrm{C}$ in Rapid Hyb (Pharmacia-Amersham Biotech.). After washing the membranes under high-stringency conditions $(0 \cdot 1 \%$ sodium dodecylsulfate, $0 \cdot 1 \times$ standard saline citrate, $65^{\circ} \mathrm{C}$, for $30 \mathrm{~min})$, they were exposed to film for $4-6 \mathrm{~h}$. The

www.endocrinology.org membranes were then stripped as described by the manufacturer and hybridized to a cDNA probe specific for the glyceraldehyde-3-phosphate dehydrogenase (G3 PDH) gene. The amount of hybridization signal was quantified with a scanning laser densitometer (Molecular Dynamics, Sunnyvale, CA, USA). 

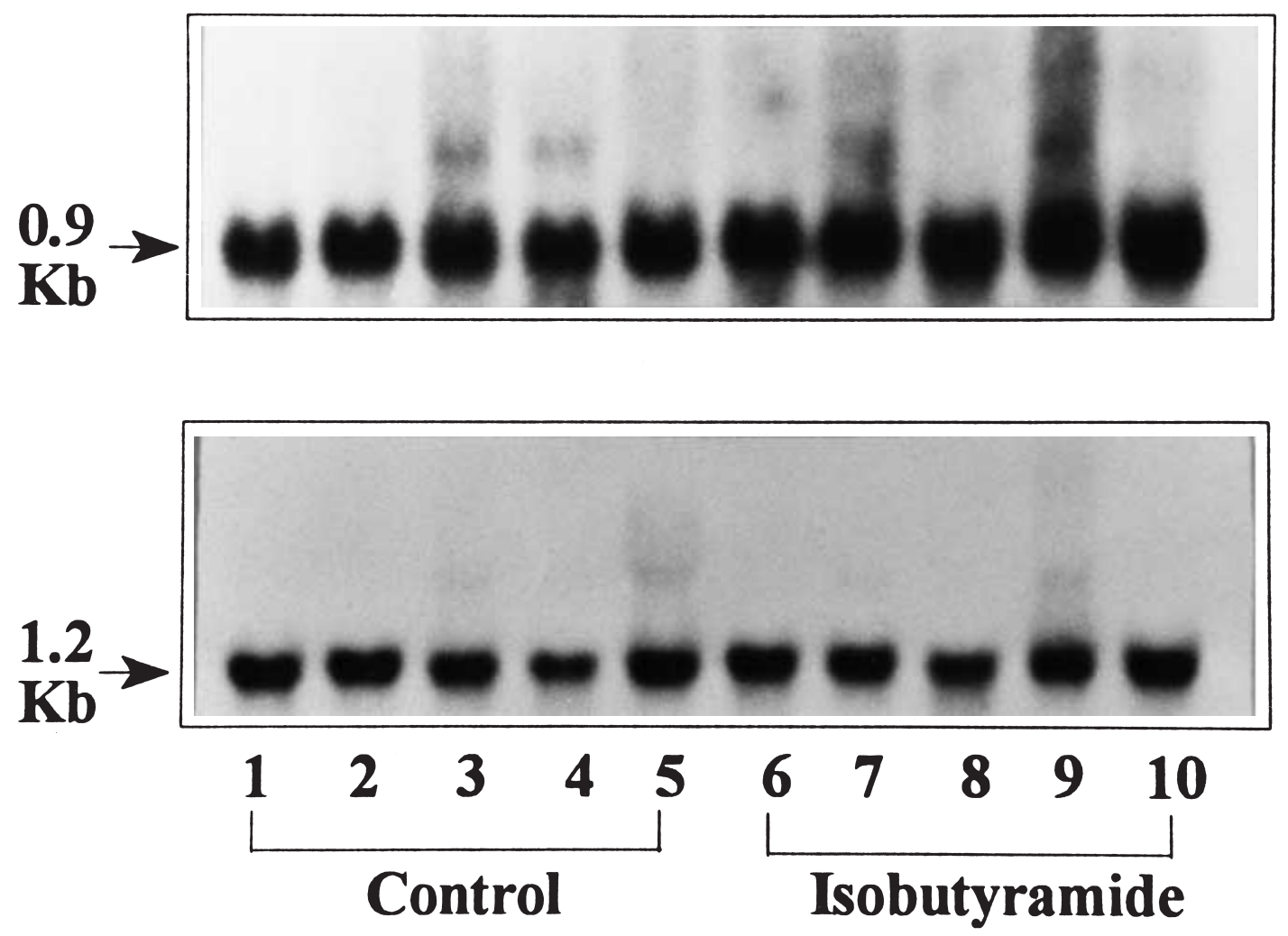

FIGURE 2. Hepatic apoA1 (top panel) and G3 PDH (bottom panel) mRNA content from control (lanes 1-5) and isobutyramide-treated animals (lanes 6-10). Isobutyramide did not significantly alter hepatic apoAI mRNA content relative to the G3 PDH control.

\section{Western blot analysis}

The specificity of the polyclonal apoAI antiserum and the method of its preparation have been described previously (Mooradian et al. 1997). Plasma protein samples $(5 \mu \mathrm{g})$ were electrophoresed in a $10 \%$ sodium dodecylsulfate (SDS)-polyacrylamide gel (Laemmli 1970), and transferred electrophoretically to a nitrocellulose membrane (Towbin et al. 1979). The membrane was incubated with the apoAI primary antibody at a final dilution of 1:10 000 for $2 \mathrm{~h}$ at room temperature. Horseradish peroxidase-linked goat-anti-rabbit $\mathrm{IgG}$ was used at a final dilution of 1:10 000 at room temperature. Blots were developed using the enhanced chemiluminescence (ECL) reagent (Pharmacia-Amersham Biotech.) as described by the manufacturer. Plasma apoAI levels were determined by densitometry using the personal densitometer from Molecular Dynamics.

\section{Statistical analysis}

Changes in reporter gene activity and mRNA expression were evaluated with the two-tailed
Student's $t$-test. A $P<0.05$ was considered the limit for statistical significance. The results are expressed as the mean \pm S.D.

\section{RESULTS}

\section{Effect of streptozotocin-induced diabetes on apoA1 gene expression}

In order to investigate whether or not diabetic ketoacidosis affects apoA1 gene expression, hepatic apoAI mRNA levels, relative to G3 PDH mRNA, were measured in streptozotocin-diabetic rats. The results were compared with age- and sex-matched nondiabetic controls (Fig. 1). All the streptozotocintreated rats were diabetic since they had blood glucose levels over $300 \mathrm{mg} / \mathrm{dl}$ and serum $\beta$-hydroxybutyrate levels two- to fourfold above normal. The hepatic apoAI mRNA content of diabetic animals $(0.45 \pm 0.05$ arbitrary units $)$ was only $58 \%$ of the apoA 1 mRNA found in the euglycemic controls $(0 \cdot 76 \pm 0 \cdot 06, \quad P<0 \cdot 027$, Fig. 1B). 

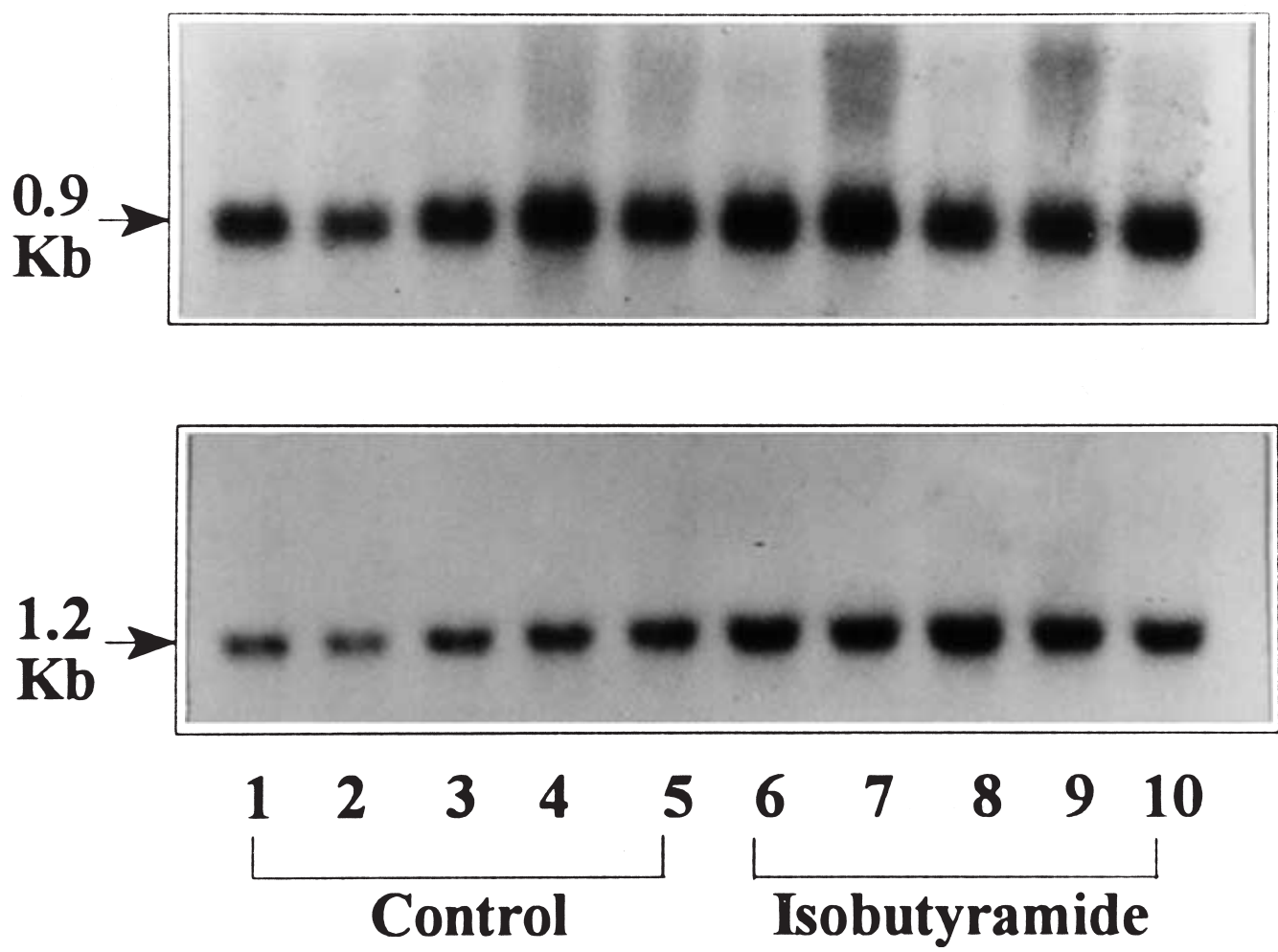

Figure 3. Expression of apoA1 (top panel) and G3 PDH (bottom panel) mRNA in the small intestine from control (lanes 1-5) and isobutyramide-treated animals (lanes 6-10).

Isobutyramide treatment did not significantly alter intestinal apoAI mRNA content relative to the G3 PDH control.

\section{Effect of ketone bodies on apoA1 gene expression}

In order to determine if ketone bodies affect apoA1 gene expression in vivo, four-month-old nondiabetic rats were given $500 \mathrm{mg} / \mathrm{kg}$ isobutyramide by gavage. Isobutyramide is an orally bioavailable butyrate analog with long plasma half-life compared with butyrate (Perrine et al. 1994). After $24 \mathrm{~h}$ isobutyramide treatment, the animals were killed, and RNA was prepared from liver and small intestine. Northern blot analysis of hepatic (Fig. 2) and intestinal (Fig. 3) RNA indicate that isobutyramide has no significant effect on apoAI mRNA content of these tissues.

Western blot analysis with serum samples obtained from these animals was also performed to determine if ketone bodies have any posttranslational effects on steady-state serum apoA1 protein levels. The relative amount of the $29 \mathrm{kDa}$ apoA1 protein did not change in the animals given isobutyramide (data not shown).

Sodium butyrate $(10 \mathrm{mM})$ and isobutyramide $(10 \mathrm{mM})$ did not alter apoAI mRNA levels in Hep G2 or Caco-2 cells in culture (data not shown).

www.endocrinology.org
These results suggest that ketone bodies, per se, do not have a readily demonstrable effect on the steady-state levels of the apoA1 message in either cultured Hep G2 or Caco-2 cells or in vivo.

\section{Effect of ketone bodies on the apoA1 gene promoter}

To determine if ketone bodies have any effects on apoAI gene transcriptional activity, reporter gene expression driven by the apoAI promoter was analyzed in cultured cells. Hep G2 liver cells and Caco-2 intestinal cells were transfected with the plasmid pA1-474.CAT, which carries the full sequence of rat apoAI gene promoter, along with the CAT reporter gene (Widom et al. 1991, Romney et al. 1992, Taylor et al. 1996, Mooradian et al. 1997, Harnish et al. 1998, Murao et al. 1998). Both of these cell lines are suitable for these studies since they express the endogenous apoA1 gene (see below). After $24 \mathrm{~h}$, the cells were treated with either sodium butyrate (Btr) and isobutyramide (Iso) at concentrations of $0 \cdot 3,1 \cdot 0,3 \cdot 0$, and $10 \cdot 0 \mathrm{mM}$. After $24 \mathrm{~h}$, the cells were harvested and assayed for CAT 
TABle 1. ApoAI promotor activity (CAT activity) in the presence of varying concentrations of butyrate and isobutyramide. Results are means \pm the variation

\begin{tabular}{|c|c|c|}
\hline & CAT acti & $\%$ acetylation) \\
\hline & Butyrate & Isobutyramide \\
\hline Con & & \\
\hline 0 & $16 \cdot 8 \pm 0 \cdot 0$ & $16 \cdot 8 \pm 0 \cdot 0$ \\
\hline $0 \cdot 3$ & $13 \cdot 0 \pm 0 \cdot 0$ & $16 \cdot 5 \pm 2 \cdot 5$ \\
\hline $1 \cdot 0$ & $18 \cdot 4 \pm 4 \cdot 8$ & $17 \cdot 7 \pm 1 \cdot 6$ \\
\hline $3 \cdot 0$ & $14 \cdot 7 \pm 1 \cdot 5$ & $14 \cdot 3 \pm 2 \cdot 4$ \\
\hline $10 \cdot 0$ & $14 \cdot 0 \pm 4 \cdot 1$ & $16 \cdot 7 \pm 1 \cdot 2$ \\
\hline
\end{tabular}

*CAT activity normalized to expression of $\beta$-galactosidase activity. No significant dose-respondent relationship is observed in the duplicate measurements. These findings were confirmed in similar experiments, repeated twice.

and $\beta$-galactosidase activity. The results (Table 1 ) show that Btr or Iso did not significantly alter CAT activity relative to $\beta$-galactosidase activity, at any dose. The activity of the CMV- $\beta$-gal reporter gene used to control for transfection efficiency was not altered when Btr or Iso were added to culture media.

\section{Effect of pH on apoAI mRNA levels}

Since the presence of ketone bodies in the absence of changes in culture media $\mathrm{pH}$ did not affect expression of the apoAI gene, we next determined whether or not acidosis affects apoAI mRNA levels in vitro. Total RNA was isolated from both Hep G2 and Caco- 2 cells maintained at either $\mathrm{pH} 6 \cdot 7$ or $7 \cdot 9$ for $24 \mathrm{~h}$, and Northern blotting was performed with probes specific for the apoAI and G3PDH mRNAs. The results (Fig. 4) indicate that apoAI mRNA content is reduced $47 \%$ and $24 \%$ during acidosis in Hep G2 $(P<0 \cdot 025$, Fig. 4A) and Caco-2 $(P<0 \cdot 017$, Fig. 4B) cells respectively. G3PDH mRNA levels were similar at $\mathrm{pH} 6.7$ and $\mathrm{pH} 7.9$, suggesting that the effect of $\mathrm{pH}$ on apoAI mRNA content is specific.

\section{Effect of $\mathrm{pH}$ on the apoA1 gene promoter}

Since apoAI mRNA levels are suppressed by acidosis, we determined whether or not the effect of acidosis is mediated through the apoA1 gene promoter. Hep G2 and Caco-2 cells were transfected with the reporter construct pA1·474.CAT. After $24 \mathrm{~h}$, the media were removed and replaced with bicarbonate-deficient DMEM maintained at the required $\mathrm{pH}$ using HEPES buffer. After $24 \mathrm{~h}$, the cells were collected and assayed for CAT and $\beta$-galactosidase activity. In Hep G2 cells, a

\section{A. Hep G2}
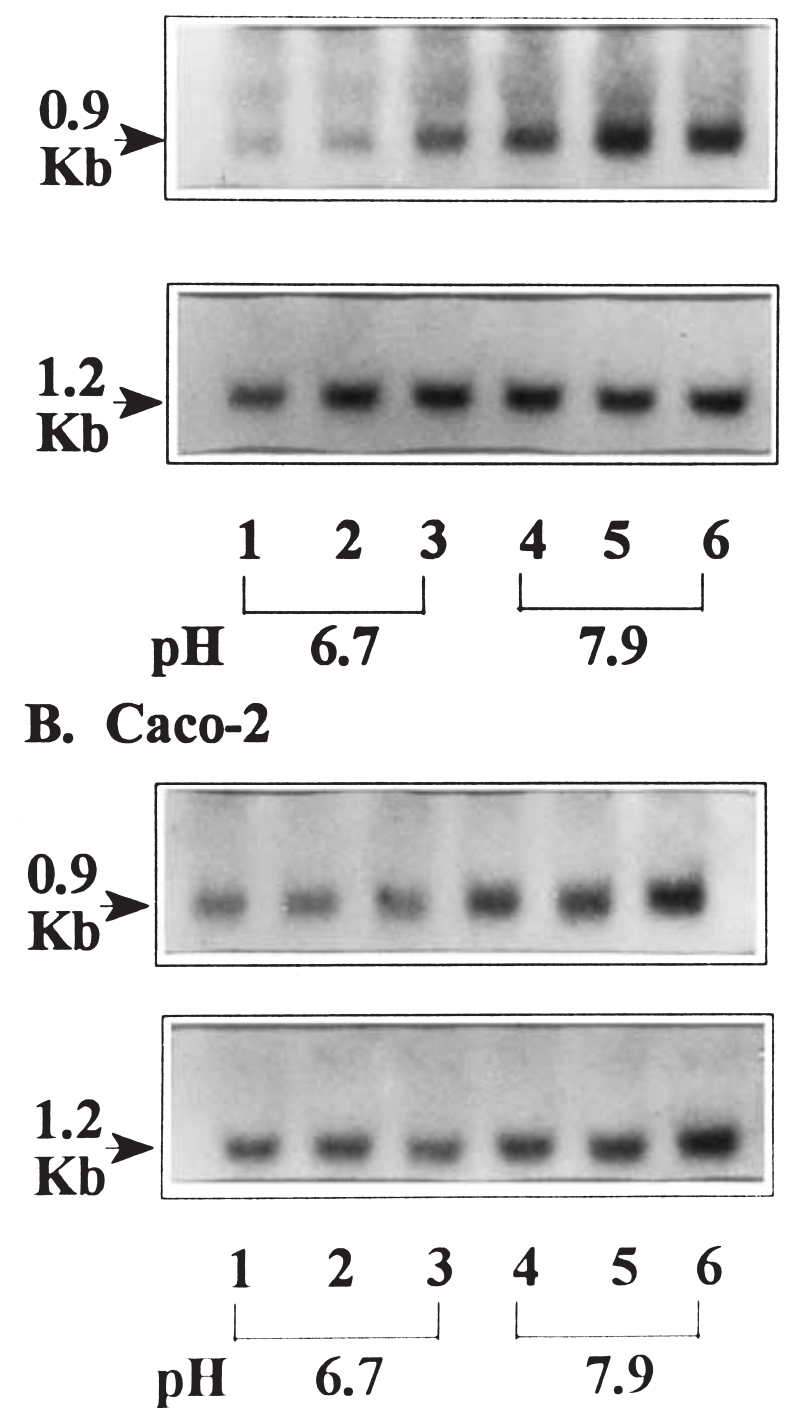

FIgURE 4. Effect of acidosis on apoAI mRNA. Total RNA was isolated from both Hep G2 (A) and Caco-2 (B) cells maintained at either $\mathrm{pH} 6.7$ (lanes 1-3) or $\mathrm{pH}$ $7 \cdot 9$ (lanes 4-6) for $24 \mathrm{~h}$. The membrane was hybridized with the rat apoAI cDNA, stripped, and rehybridized with the G3PDH cDNA. The amount of signal generated with the apoAI probe was normalized to the amount obtained with the G3PDH probe. The increase in apoAI mRNA $(0.9 \mathrm{~kb})$ relative to $\mathrm{G} 3 \mathrm{PDH}$ mRNA $(1 \cdot 2 \mathrm{~kb})$ is evident at $\mathrm{pH} 7 \cdot 9$ compared with pH $6 \cdot 7$.

reduction in extracellular $\mathrm{pH}$ from 7.9 to 6.7 gradually decreased CAT activity more than fourfold (Fig. 5 and Table 2). A similar trend was also observed in Caco-2 cells (Fig. 6 and Table 2). 


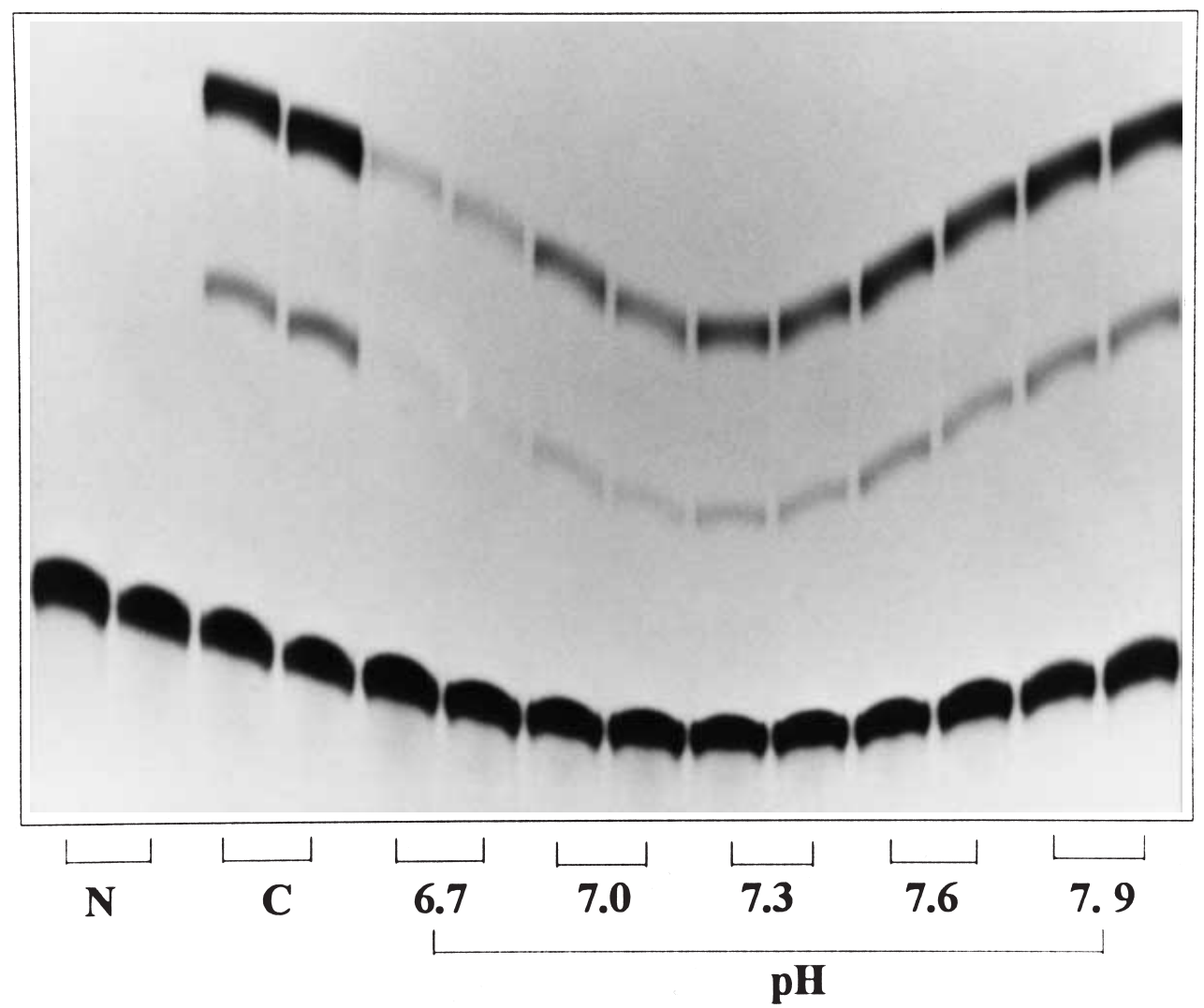

FIGURE 5. ApoA1 gene promoter activity in Hep G2 cells cultured in media with varying pH. Hep G2 cells were transfected with pA1 474.CAT (full-length apoA1 promoter) and after $24 \mathrm{~h}$, the media were removed and replaced with growth media adjusted to $\mathrm{pH} 6 \cdot 7$, $7 \cdot 0,7 \cdot 3,7 \cdot 6$, and $7 \cdot 9$. Control media (C) contain sodium bicarbonate. The sagging appearance of the acetylated products is occasionally observed when large TLC plates are used. Reduced ${ }^{14} \mathrm{C}$-chloramphenicol acetylation at $\mathrm{pH} 6.7$ compared with higher $\mathrm{pH}$ is evident. The quantitative results are presented in Table 2. N, nontransfected cells; C, cells cultured in bicarbonate-containing media.

The activity of the cytomegalo virus (CMV)$\beta$-gal control plasmid was reduced in some experiments $20-25 \%$ at the lowest $\mathrm{pH}$, but did not change from $\mathrm{pH} 7.0$ to 7.9 (data not shown). This slight decrease in $\beta$-galactosidase activity may be due to the effect of an acidic environment on protein synthesis in some cell lines (Yamaji et al. 1994). In order to determine if the change in apoAI promoter activity we observed with acidosis is not an artifact of the assay or culture conditions, we transfected Caco-2 cells with the plasmid $\mathrm{pSV}_{2} \mathrm{CAT}$, which contains the simian virus 40 (SV40) early-region promoter fused to the CAT reporter gene. After $24 \mathrm{~h}$, the media were adjusted to either $\mathrm{pH} 6.7$ or $7 \cdot 9$, and after a further $24 \mathrm{~h}$, the cells were harvested and assayed for CAT

www.endocrinology.org
TABLE 2. Effect of varying ambient $\mathrm{pH}$ on apoAI promotor activity (CAT activity) in Hep G2 and Caco-2 cells. Results are means \pm the variation

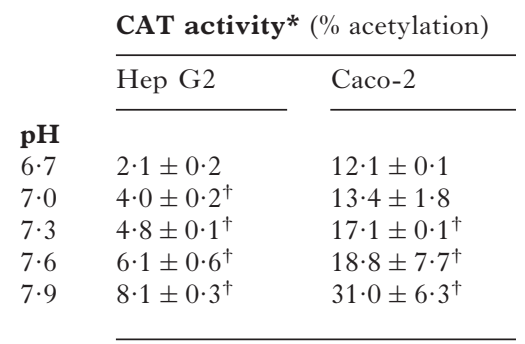

* CAT activity is normalized to $\beta$-galactosidase activity. ${ }^{\dagger} P<0.05$ compared to the measurements at $\mathrm{pH} 6.7$.

The graded increase in CAT activity with increasing $\mathrm{pH}$ is evident in both cell lines. 


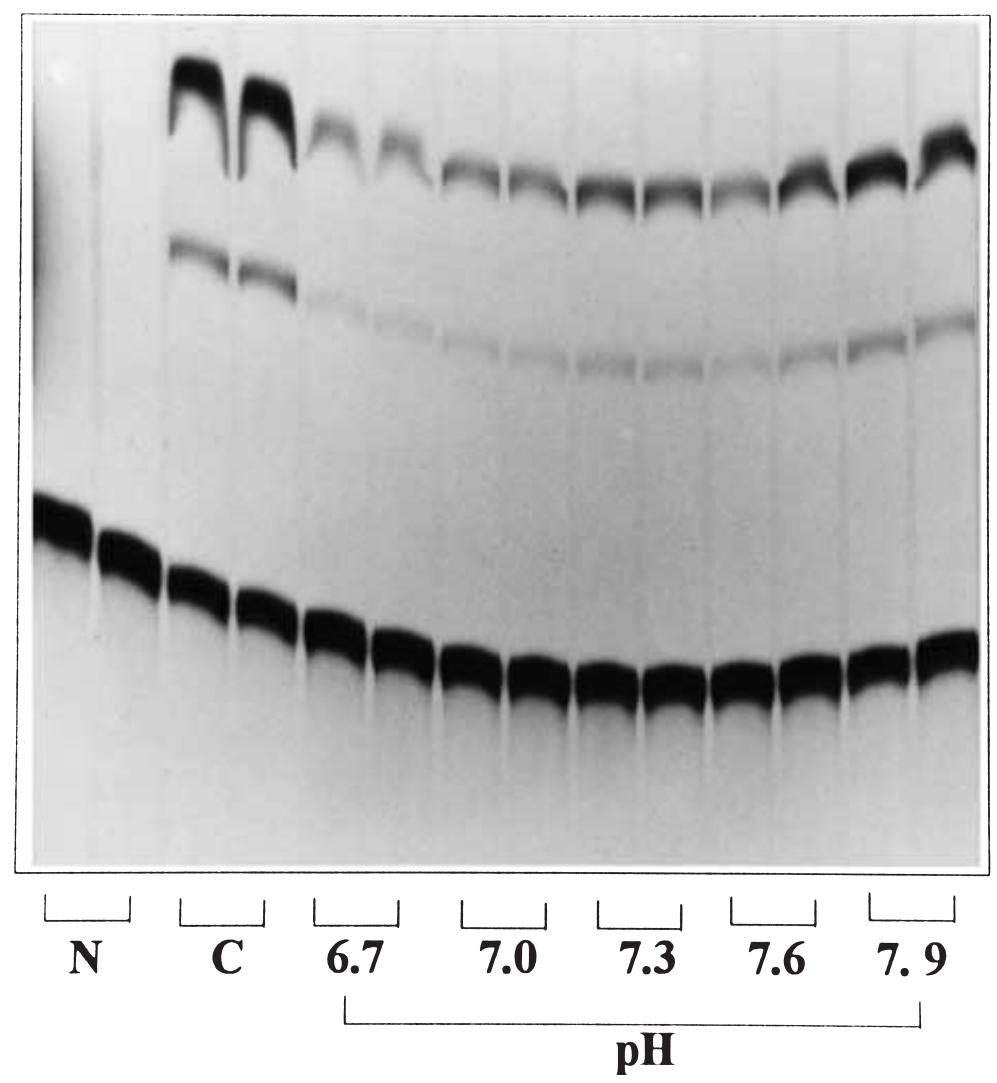

FIGURE 6. ApoA1 gene promoter activity in Caco-2 cells cultured in media with varying $\mathrm{pH}$. Caco-2 cells were transfected with pA1 474.CAT (full-length apoA1 promoter) and after $24 \mathrm{~h}$, the media were removed and replaced with growth media adjusted to $\mathrm{pH} 6 \cdot 7$, $7 \cdot 0,7 \cdot 3,7 \cdot 6$, and $7 \cdot 9$. Control media (C) contain sodium bicarbonate. Reduced ${ }^{14} \mathrm{C}$-chloramphenicol acetylation at $\mathrm{pH} 6.7$ compared with higher $\mathrm{pH}$ is evident. The quantitative results are presented in Table 2. N, nontransfected cells; C, cells cultured in bicarbonate-containing media.

activity. The results (Fig. 7) indicate that the SV40 early-region promoter activity is not significantly altered by changing the ambient $\mathrm{pH}$. These data support the conclusion that the rat apoA1 gene promoter, unlike the SV40 earlyregion promoter, is sensitive to changes in extracellular $\mathrm{pH}$.

\section{DISCUSSION}

The association of heart disease with diabetes has been reported in several epidemiological studies and requires an explanation at the molecular level. Glucose and insulin regulate expression of the apoA1 gene in the liver (Murao et al. 1998) through an insulin response core element (IRCE) located in the $5^{\prime}$-flanking region of the rat apoA1 gene. The IRCE present in the apoAI promoter is related to the IRCEs identified in the G3PDH gene and glucagon gene (Nasrin et al. 1990, Philippe 1991). This process may have a role in reducing apoA1 mRNA expression in diabetic animals (Fig. 1).

Since four-month-old rats with severe streptozotocin-induced diabetes have low hepatic apoAI mRNA levels (Fig. 1), we wished to determine if, in addition to hyperglycemia and insulin deficiency, ketoacidosis also affects expression of the apoA1 gene in the liver and small intestine. Small chain fatty acids, such as sodium butyrate, are structurally similar to the ketone bodies that are elevated in diabetic ketoacidosis. Sodium butyrate regulates gene expression (Ortiz-Caro et al. 1986, Lazar 1990, deFazio et al. 

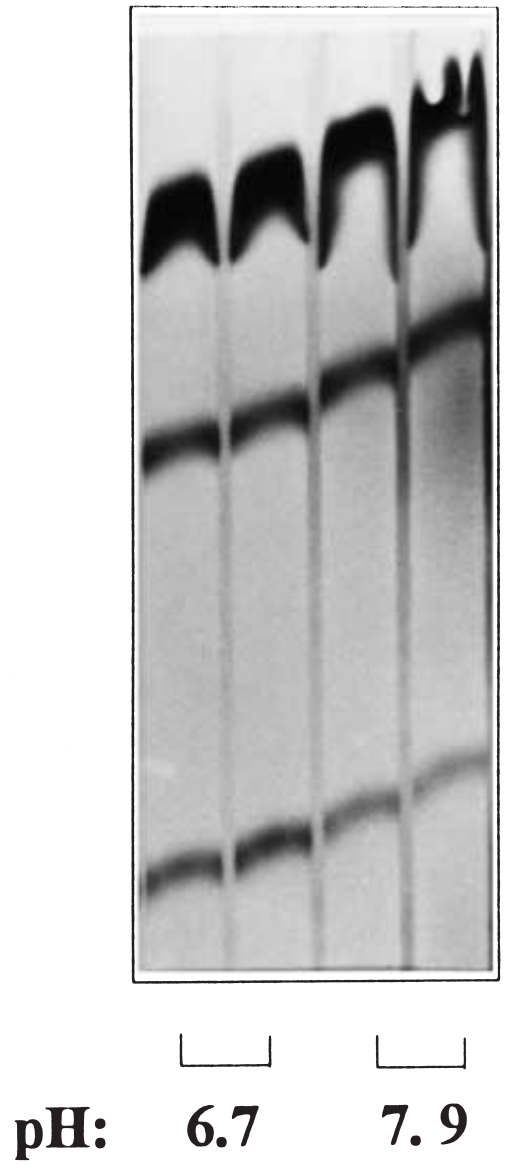

\section{CAT Activity: $\quad 83.1 \quad 73.2$ $\pm 3.3 \quad \pm 3.9$}

FIGURE 7. Caco-2 cells were transfected with $\mathrm{pSV}_{2} \mathrm{CAT}$ and after $24 \mathrm{~h}$, the media were exchanged with HEPESbuffered media at either $\mathrm{pH} 6 \cdot 7$ or $7 \cdot 9$. After another $24 \mathrm{~h}$, cells were harvested and assayed for CAT activity. The change in media $\mathrm{pH}$ did not significantly alter CAT activity when normalized to $\beta$-galactosidase activity.

1992, Zitnik et al. 1995) by enhancing histone acetylation through inhibition of histone deacetylase activity (Turner 1993), by activating phosphatase activity (Cuisset et al. 1997), or by other means that await discovery. The present studies evaluating the ability of butyrate to modulate expression of the rat apoA1 gene through its promoter in vitro, did not show any change in CAT activity relative to untreated controls (Table 1). Isobutyramide (Iso), a derivative of $\mathrm{Btr}$ with a longer plasma half-life in vivo (Perrine et al. 1994), also had no effect on CAT activity in transfected liver cells (Table 1). In addition, there were no changes in apoA $1 \mathrm{mRNA}$ or protein content in either the liver or small intestine of animals treated with Iso (Figs 2 and 3), suggesting that our in vitro studies are consistent with the in vivo data. These observations suggest that ketone bodies, per se, have no demonstrable effect on the expression of the apoA1 gene.

In contrast to the lack of a demonstrable effect of ketone bodies on apoAI mRNA content or apoAI promoter activity, our experiments demonstrate that apoA1 expression is extremely sensitive to variations in extracellular $\mathrm{pH}$. This effect is observed in both the liver and intestinal cell lines (Figs 5 and 6, and Table 2), suggesting that the signal elicited by the change in $\mathrm{pH}$ is conserved, and most likely mediated, by a mechanism common to both cell lineages. ApoAI gene expression in the region of the small intestine proximal to the duodenum may be sensitive to acidosis during the daily excursions in $\mathrm{pH}$ associated with feeding and the emptying of stomach contents. The resulting acidic environment is transient due to the rapid activation of bicarbonate/chloride pumps located in the intestinal epithelial cell. Whether or not bicarbonate ions affect expression of the apoAI gene remains to be examined. An acidic extracellular $\mathrm{pH}$ is sometimes associated with decreases in protein synthesis in some cell lines (Yamaji et al. 1994). We occasionally observed a similar phenomenon in some of our experiments when assessing both CAT and $\beta$-galactosidase activity at $\mathrm{pH} 6 \cdot 7$, the lowest value we examined. Experiments with the SV40 virus early-region promoter (Fig. 7), however, indicate that the activity of this promoter at $\mathrm{pH} 6.7$ and $\mathrm{pH} 7.9$ is equivalent. Furthermore, the relative specificity of our findings is also indicated by the observation that apoAI mRNA levels were reduced relative to the G3PDH mRNA (Fig. 4).

The acidosis that occurs in ketotic animals has the potential of affecting the expression of various genes. Previously published studies have shown that several genes in the kidney respond at the transcriptional level to changes in $\mathrm{pH}$ (Yamaji et al. 1994). The activity of the transcription factor early growth response factor one (EGR-1), as well as mRNA levels for several transcription factors involved in immediate-early gene expression, are elevated by a protein tyrosine kinase-dependent pathway when kidney epithelial cells are exposed to an acidic environment (Yamaji et al. 1994). Tyrosine kinase inhibitors substantially reduce the effect of acidosis on transcription, but the actual kinases involved in the signal transduction cascade remain to be elucidated. Interestingly, the apoAI gene promoter has an EGR-1 binding site (Kilbourne et al. 1995) which may be responsible for the $\mathrm{pH}$ effect described here. Acidosis may 
enhance the ability of EGR-1 to bind the apoAI promoter and either act as a transcriptional repressor or prevent the activity of another transcription inducing factor. Alternatively, acidosis may affect the tertiary structure of the apoAI promoter. The rate of base depurination as well as strand dissociation are enhanced in an acidic environment. Unless the apoAI promoter has a region that is particularily sensitive to these changes, this effect would also most likely affect the expression of other genes. It is more likely that the effect of acidosis is mediated by a trans-acting repressor for two reasons. First, repression by acidosis is specific for the apoAI promoter. The SV40 virus early-region promoter was not significantly repressed when the $\mathrm{pH}$ was dropped to $\mathrm{pH}$ $6 \cdot 7$ (Fig. 7). Secondly, a slight reduction in reporter gene activity is evident with each gradual change in $\mathrm{pH}$. The lack of a threshold phenomenon suggests that an intracellular $\mathrm{pH}$ 'sensor' is gradually engaged when the $\mathrm{pH}$ is altered (Figs 5 and 6). Experiments to characterize the cis-element(s) involved in regulating apoAI gene expression by acidosis, as well as characterizing the roles of tyrosine kinases and protein kinase $\mathrm{C}$ on mediating the affect of acidosis on apoAI gene expression, are currently under way.

In summary, these observations indicate that ketoacidosis suppresses apoA1 gene expression. The effect is solely the result of acidemia and is not related to increased ketone body concentration. These changes in apoA1 mRNA synthesis may contribute to the high incidence of coronary atherosclerotic heart disease in type 1 diabetic subjects and to the decreased apoAI level observed in children with chronic renal failure and metabolic acidosis (Bircan et al. 1997).

\section{REFERENCES}

Barter PJ \& Ryek A 1996 High density lipoproteins and coronary heart disease. Atherosclerosis 121 1-12.

Bircan Z, Kaplan A, Soran M, Soker M, Kervancioglu M, Sahin A \& Kilinc M 1997 The effect of metabolic acidosis on serum apolipoprotein A1 and apolipoprotein B levels in children with chronic renal failure. International Fournal of Urology and Nephrology 29 603-607.

Cassuto H, Olswang Y \& Levoff AF 1997 Involvement of HNF-1 in the regulation of phosphoenolpyruvate carboxykinase gene expression in the kidney. FEBS Letters 412 597-602.

Chirgwin JM, Przybylz AE, MacDonald RJ \& Rutter WJ 1979 Isolation of biologically active ribonucleic acid from sources enriched in ribonuclease. Biochemistry 18 5294-5299.

Cuisset L, Ticnonicky L, Jaffray P \& Delpech M 1997 The effects of sodium butyrate on transcription are mediated through activation of a protein phosphatase. Fournal of Biological Chemistry 272 24148-24153.
Despres JP, Lamarche B, Mauriege P, Cantin B, Dagenais GR, Moorjani S \& Lupien PJ 1996 Hyperinsulinemia as an independent risk factor for ischemic heart disease. New England Fournal of Medicine 334 952-957.

deFazio A, Chiew YE, Donoghue C, Lee GS \& Sutherland RL 1992 Effect of sodium butyrate on estrogen receptor and epidermal growth factor receptor gene expression in human breast cancer cell lines. Fournal of Biological Chemistry 267 18008-18012.

Forte TM \& McCall MR 1994 The role of apolipoprotein A-I-containing lipoproteins in atherosclerosis.. Current Opinion in Lipidology 5 354-364.

Franceschini G, Maderna P \& Sirtori CR 1991 Reverse cholesterol transport: physiology and pharmacology. Atherosclerosis $\mathbf{8 8}$ 99-107.

Gorman CM, Moffat LF \& Howard BH 1982 Recombinant genomes which express chloramphenicol acetyltransferase in mammalian cells. Molecular and Cellular Biology 2 1044-1051.

Haffner SM, Lehtos S, Ronnemaa T, Pyorala K \& Laakso M 1998 Mortality from coronary heart disease in subjects with type 2 diabetes and in nondiabetic subjects with and without prior myocardial infarction. New England Fournal of Medicine 339 229-234.

Harnish DC, Evans MJ, Scicchitano MS, Bhat RA \& Karathanasis SK 1998 Estrogen regulation of the apolipoprotein A1 gene promoter through transcription factor sharing. Fournal of Biological Chemistry 273 9270-9278.

Herbomel P, Bourachot B \& Yaniv M 1984 Two distinct enhancers with different cell specificities coexist in the regulatory region of polyoma. Cell $39653-662$.

Kilbourne EJ, Widom R, Harnish DC, Malik S \& Karathatnasis SK 1995 Involvement of early growth response factor Egr-1 in apolipoprotein A1 gene transcription. Fournal of Biological Chemistry 270 7004-7010.

Laemmli UK 1970 Cleavage of structural proteins during the assembly of the head of bacteriophage T4. Nature 227 680-685.

Lazar MA 1990 Sodium butyrate selectively alters thyroid hormone receptor gene expression in GH3 cells. Fournal of Biological Chemistry 265 17474-17477.

Miller GJ \& Miller NE 1975. Plasma high-density lipoprotein concentration and development of ischaemic heart disease. Lancet 1 16-19.

Mooradian AD \& Nowak FV 1996 Diabetes mellitus and heart disease. In Cardiovascular Disease in Older Persons, pp 53-72. Eds FE Kaiser, JE Morley \& RM Coe. New York: Springer Verlag.

Mooradian AD, Wong NCW \& Shah GN 1997 Apolipoprotein A1 expression in young and aged rats is modulated by dietary carbohydrates. Metabolism 46 1132-1136.

Murao K, Wada Y, Nakamura T, Taylor AH, Mooradian AD \& Wong NCW 1998 Effects of glucose and insulin on rat apolipoprotein A-1 gene expression. Fournal of Biological Chemistry 273 18959-18965.

Nasrin N, Ercolani L, Denaro M, Kong XF, Fang I \& Alexander M 1990 An insulin response element in the glyceraldehyde-3-phosphate dehydrogenase gene binds a nuclear protein induced by insulin in cultured cells and by nutritional manipulations in vivo. PNAS 87 5273-5277.

Ortiz-Caro J, Montiel F, Pascual A \& Aranda A 1986 Modulation of thyroid hormone nuclear receptors by short-chain fatty acids in glial C6 cells. Role of histone acetylation. Fournal of Biological Chemistry 261 1399714004.

Perrine SP, Dover GH, Daftari P, Walsh CT, Jin YX, Mays A \& Fuller DV 1994 Isobutyramide, an orally available 
butyrate analogue, stimulates fetal globin gene expression in vitro and in vivo. British Fournal of Haematology $\mathbf{8 8}$ 555-561.

Philippe J 1991 Insulin regulation of the glucagon gene is mediated by an insulin-responsive DNA element. PNAS $\mathbf{8 8}$ 7224-7227.

Romney JS, Chan J, Carr FE, Mooradian AD \& Wong NCW 1992 Identification of the thyroid hormone responsive messenger RNA spot11 as apolipoprotein A1 messenger RNA and effects of the hormone on promoter activity. Molecular Endocrinology 6 943-950.

Sambrook J, Fritsch EF \& Maniatis T 1989 Molecular Cloning: A Laboratory Manual, edn 2. New York: Cold Spring Harbor Laboratory, Cold Spring Harbor.

Solymoss BC, Marcil M, Chasur M, Giffix BU, Poitras AM \& Campeau L 1995 Fasting hyperinsulinism, insulin resistance syndrome, and coronary heart disease in men and women. American Fournal of Cardiology 76 1152-1156.

Taylor AH, Wishart P, Lawless DE, Raymond J \& Wong NCW 1996 Identification of functional positive and negative thyroid hormone-response elements in the rat apolipoprotein A1 promoter. Biochemistry 35 8281-8288.

Towbin H, Staehelin T \& Gordon J 1979 Electrophoretic transfer of proteins from polyacrylamide gels to nitrocellulose sheets. PNAS 76 4350-4354.

Turner BM 1993 Decoding the nucleosome. Cell 75 65-82.

Widom RL, Ladias JAA, Kouidou S \& Karathanasis SA 1991 Synergistic interactions between transcription factors control expression of the apolipoprotein A1 gene in liver cells. Molecular and Cellular Biology 11 677-687.

Yamaji Y, Moc OW, Miller RT \& Alpern RJ 1994 Acid activation of immediate early genes in renal epithelial cells. Fournal of Clinical Investigation 94 1297-1303.

Zitnik G, Peterson K, Stamatoyanopouos G \& Papayannoupolous T 1995 Effects of butyrate and glucocorticoids on gamma- to beta-globin gene switching in somatic cell hybrids. Molecular and Cellular Biology 15 790-795.

RECEIVED 22 December 1999 